\title{
Pengasuhan Orangtua dan Penalaran Moral: Kajian Meta-Analisis
}

\author{
MM Shinta Pratiwi \\ Fakultas Psikologi, Universitas Semarang \\ shinta@usm.ac.id \\ Subandi \\ Fakultas Psikologi, Universitas Gadjah Mada Yogyakarta \\ subandi@ugm.ac.id \\ Maria Goretti Adiyanti \\ Fakultas Psikologi, Universitas Gadjah Mada Yogyakarta \\ adiyanti_psi@ugm.ac.id
}

\begin{abstract}
Research on the relationship between parenting with moral reasoning has been done by many researchers because of the increasing of moral decadence problem. Various studies about parenting with moral reasoning showed varying results. Research on parenting style with moral reasoning also showed varying results. The purpose of this study is to determine the relationship between parenting with moral reasoning through the meta-analysis study. Total studies used were 20 articles with 72 studies with 15343 subjects. Meta-analyzes were done based on the calculation of sampling error and measurement error. The results of metaanalyzes indicate that generally there is a correlation between parenting to moral reasoning is low $(\check{r}=0,04)$. The impact of sample error of $29.97 \%$. Results of a meta-analysis of the types of parenting styles showed that parenting style such as authoritative, authoritarian, and permissive had a relationship with moral reasoning. The results of the research grouping by type of parenting style showed different results on the correlation results with moral reasoning. Authoritative parenting style $(\check{r}=0,046)$ had a greater correlation than authoritarian parenting styles $(\check{r}=0,015)$ and permissive $(\check{r}=-0,038)$.
\end{abstract}

Keywords: meta-analysis; parenting; moral reasoning

\begin{abstract}
Abstrak
Penelitian tentang hubungan antara pengasuhan orangtua dengan penalaran moral semakin banyak dilakukan. Berbagai hasil penelitian tentang pengasuhan orangtua dengan penalaran moral menunjukkan hasil yang bervariasi. Tujuan studi ini adalah untuk mengetahui hubungan antara pengasuhan orangtua dengan penalaran moral melalui studi meta-analisis. Total studi yang dipergunakan adalah 20 artikel dengan 72 studi dengan 15343 subjek. Meta-analisis yang dilakukan berdasarkan perhitungan kesalahan sampling dan kesalahan pengukuran. Hasil meta-analisis
\end{abstract}


menunjukkan bahwa bahwa secara umum ada korelasi antara pengasuhan orangtua dengan penalaran moral tergolong rendah $(\check{\mathrm{r}}=0,04)$. Dampak kesalahan sampel sebesar 29,97\%. Hasil meta-analisis terhadap jenis gaya pengasuhan menunjukkan bahwa gaya pengasuhan otoritatif, otorian, dan permisif memiliki hubungan dengan penalaran moral. Hasil pengelompokan penelitian berdasarkan jenis gaya pengasuhan menunjukkan hasil yang berbeda pada hasil korelasi dengan penalaran moral. Gaya pengasuhan otoritatif $(\check{\mathrm{r}}=0,046)$ memiliki korelasi yang lebih besar daripada gaya pengasuhan otoritarian $(\breve{\mathrm{r}}=0,015)$ dan permisif $(\breve{\mathrm{r}}=-$ 0,038 )

Kata kunci : meta-analisis; pengasuhan orangtua; penalaran moral

\section{Pendahuluan}

Moralitas secara umum dikaitkan dengan nilai-nilai kemanusiaan dan berhubungan dengan perilaku yang boleh atau tidak boleh dilakukan. Proses perkembangan moral sesuai dengan konsep dasarnya mengenai perkembangan kognitif (Papalia,2008). Piaget berpendapat bahwa pemahaman moral berkembang bertahap sesuai dengan fenomena sosial dan relasi anak dengan lingkungannya. Penalaran moral yang sering disebut juga moral reasoning, moral judgment, atau moral thinking yang merupakan bagian dari kemampuan kognitif (Forney, Forney, \& Crutsinger, 2005) yang digunakan untuk membantu individu memecahkan dilema moral yang biasanya muncul dalam situasi yang ambigu. Tokoh lain, selain Piaget, yang mengungkapkan tentang perkembangan moral adalah Kohlberg. Kohlberg (dikutip dari Lickona, 1987) sependapat dengan Piaget bahwa pemahaman moral anak tidak dapat dipisahkan dari tingkat penalaran anak terhadap fenomena sosial yang di dalamnya terdapat berbagai norma. Kohlberg (dalam Berndt, 1992; Hetherington \& Parke, 1999; Gump, Baker, \& Roll, 2000; Papalia, 2008; Santrock, 2007) mengembangkan teori kognitif dan perkembangan moral

Terbentuknya nilai moral anak dapat dipengaruhi oleh pengaruh lingkungan terdekat anak. Lingkungan terdekat anak adalah keluarga. Pendidikan moral diajarkan oleh orangtua kepada anak dalam konteks lingkungan keluarga dan bukan sekolah yang semata-mata mengajar tentang pendidikan moral (Rashid, Mamat, \& Ibrahim, 2014). Orangtua yang harus bertanggung jawab utama untuk 
pengembangan moral generasi masa depan. Orangtua juga harus memiliki tujuan untuk mengamankan moralitas anak-anak karena itu adalah inti dari manusia (Rashid et al., 2014).

Berdasarkan hasil dari suatu penelitian menjelaskan bahwa kehangatan orangtua, adanya simpati, dan penalaran moral prososial adalah prediksi dari perilaku prososial (Carlo, Mestre, Samper, Tur, \& Armenta, 2011). Orangtua yang memiliki gaya pengasuhan otoriter dan pengabaian menjadi prediktor munculnya aktivitas remaja yang berkaitan dengan media yang kurang bermoral (Azari \& Faramarzi, 2014). Remaja membutuhkan dukungan dari keluarga untuk mencapai prinsip-prinsip moral dan nilai-nilai. Suasana keluarga dan jenis interaksi antara orangtua dan remaja memiliki efek penting pada pembentukan kepribadian. Akibatnya, keluarga memegang peranan penting dalam munculnya atau pencegahan perilaku patologis dan bermoral pada remaja.

Beberapa penelitian telah dilakukan untuk menyelidiki hubungan antara peran orangtua terhadap perkembangan moral remaja, namun belum banyak yang melakukan studi meta-analisis untuk melihat pola umum keterhubungan dari variabel penalaran moral dengan pengasuhan orangtua. Salah satu contoh penelitian meta-analisis yang berkaitan dengan perkembangan moral adalah studi meta-analisis untuk mengetahui hubungan antara atribusi emosi moral dengan perilaku prososial dan antisosial (Malti \& Krettenauer, 2013). Hasil studi metaanalisis tersebut menunjukkan bahwa atribusi emosi moral memiliki hubungan dengan perilaku prososial dan antisosial pada individu usia empat sampai 20 tahun. Oleh karena itu, perlu melakukan studi meta-analisis untuk meneliti keajegan atau ketidakajegan pengaruh orangtua terhadap penalaran moral. Penelitian ini bermanfaat sebagai dasar untuk peneliti lain untuk melakukan penelitian tentang penalaran moral.

\section{Metode}

Meta-analisis merupakan suatu teknik yang memiliki tujuan untuk mengestimasi tingkat hubungan dari penelitian-penelitian yang telah dilakukan (Hunter \& Schmidt, 2004). Pengumpulan data dalam penelitian ini dilakukan 
dengan menelusuri jurnal pada beberapa media elektronik seperti digital library, internet, maupun koleksi jurnal perpustakaan. Penelusuran jurnal dilakukan melalui program EBSCO, SagePubonline, Proquest, dan Spinger. Kata kunci yang digunakan untuk penelusuran jurnal adalah moral development, moral reasoning, moral judgment, morality, parenting, dan style parenting.

Tahap berikutnya adalah dengan memilih penelitian yang mempunyai informasi data tentang karakteristik partisipan, jumlah partisipan (N), nilai korelasi (r), dan koefisien reliabilitas $\left(\mathrm{r}_{\mathrm{xy}}\right)$. Kemudian melakukan transformasi nilai/koefisien F atau t ke $\mathrm{r}$ dan d. Selanjutnya adalah melakukan koreksi terhadap artifak atau ketidaksempurnaan penelitian. Studi meta-analisis digunakan sebagai dasar untuk menolak atau menerima hipotesis yang diajukan. Dua artifak yang dianalisis, yaitu kesalahan sampling dan kesalahan pengukuran (Hunter \& Schmidt, 2004) : (1) melakukan bare-bones meta-analisis, yaitu suatu metode analisis yang digunakan untuk mengetahui koreksi kesalahan sampel dengan cara menghitung: (a) rerata korelasi populasi, (b) varians rxy $(\sigma 2 \mathrm{r})$, (c) varians kesalahan pengambilan sampel ( $\sigma 2 \mathrm{e})$, (d) dampak pengambilan sampel; (2) melakukan koreksi kesalahan pengukuran dengan cara menghitung (a) rerata reliabilitas alat ukur, (b) koreksi kesalahan pengukuran, (c) jumlah koefisien kuadrat variasi (V), (d) varians yang mengacu variasi artifak, (e) varians korelasi sesungguhnya, (f) interval kepercayaan, dan (g) dampak variasi reliabilitas

\section{Hasil dan Pembahasan}

Berdasarkan hasil penelusuran dengan menggunakan kata kunci moral development, moral reasoning, moral judgment, morality, parenting, dan style parenting diperoleh 34 artikel, baik yang telah dipublikasikan melalui jurnal ilmiah maupun hasil penelitian tesis/disertasi yang dipublikasikan melalui internet dalam periode tahun 1984 hingga 2016. Tujuan dilakukannya kegiatan ini adalah untuk melihat apakah variabel pengasuhan yang diteliti dalam berbagai studi jika dirangkum ke dalam kerangka pikir penalaran moral memberikan hasil yang konsisten dan bisa dijadikan dasar untuk menjawab pertanyaan mengenai hubungan antara pengasuhan dengan pengasuhan orangtua. 
Tabel 1. Karakteristik Alat Ukur dan Contoh Penelitian

\begin{tabular}{|c|c|c|c|c|c|c|c|c|}
\hline No & Peneliti & $\begin{array}{c}\text { Alat Ukur } \\
\text { Variabel X }\end{array}$ & $\mathbf{r}_{\mathrm{xx}}$ & $\begin{array}{l}\text { Alat Ukur } \\
\text { Variabel Y }\end{array}$ & $\mathbf{r}_{\mathbf{y y}}$ & $\mathbf{r}_{\mathrm{xy}}$ & $\mathbf{N}$ & $\begin{array}{c}\text { Karakteristi } \\
\text { k Sampel }\end{array}$ \\
\hline \multirow[t]{9}{*}{1} & (Kiitredge, & Parent Rating & Data & Defining & 0,81 & & 26 & Remaja dan \\
\hline & 1984) & Scales for & tidak & Issues & & & & Ibu di \\
\hline & & Parents of & disaji & Test (DIT) & & & & Arlington \\
\hline & & Adolescent & kan & & & & & Public \\
\hline & & Children & & & & & & School \\
\hline & & & & & & & & System di \\
\hline & & & & & & & & Dutchess \\
\hline & & & & & & & & Country, \\
\hline & & & & & & & & New York \\
\hline \multirow[t]{22}{*}{2} & (Hart, 1988) & Parental & Data & Moral & 0,98 & & & Remaja dan \\
\hline & & Questionnaires & tidak & Judgment & & & & orangtua di \\
\hline & & & disaji & Interview & & & & New York \\
\hline & & & & $(M J I)$ & & & & \\
\hline & & Parental & & & & -0.15 & 10 & \\
\hline & & Questionnaires & & & & & & \\
\hline & & (Mother & & & & & & \\
\hline & & Involvement) & & & & & & \\
\hline & & & & & & 0,09 & 18 & \\
\hline & & & & & & 0,37 & 15 & \\
\hline & & & & & & $-0,18$ & 13 & \\
\hline & & & & & & 0,39 & 12 & \\
\hline & & & & & & 0,31 & 12 & \\
\hline & & Parental & & & & 0,79 & 7 & \\
\hline & & Questionnaires & & & & & & \\
\hline & & (Father & & & & & & \\
\hline & & Involvement) & & & & & & \\
\hline & & & & & & 0,56 & 12 & \\
\hline & & & & & & 0,66 & 9 & \\
\hline & & & & & & 0,48 & 9 & \\
\hline & & & & & & 0,74 & 9 & \\
\hline & & & & & & $-0,07$ & 7 & \\
\hline \multirow[t]{3}{*}{3} & (Lawrence $\mathrm{J}$ & Developmental & 0,87 & Moral & 0,8 & & 63 & Remaja dan \\
\hline & Walker \& & Environments & & Judgment & & & & orangtua di \\
\hline & Taylor, 1991) & $\begin{array}{l}\text { Coding System } \\
(D E C S)\end{array}$ & & Test (MJT) & & & & Columbia \\
\hline \multirow[t]{5}{*}{4} & (Speicher, & Adult Interview & Data & Kohlberg & 0,92 & 0,44 & 92 & Anak di \\
\hline & 1992) & & tidak & Moral & & & & California \\
\hline & & & disaji & Judgment & & & & \\
\hline & & & kan & Interviews & & & & \\
\hline & & Children's & & & & 0,48 & & \\
\hline
\end{tabular}


(Lanjutan) Tabel 1. Karkateristik Alat Ukur dan Contoh Penelitian

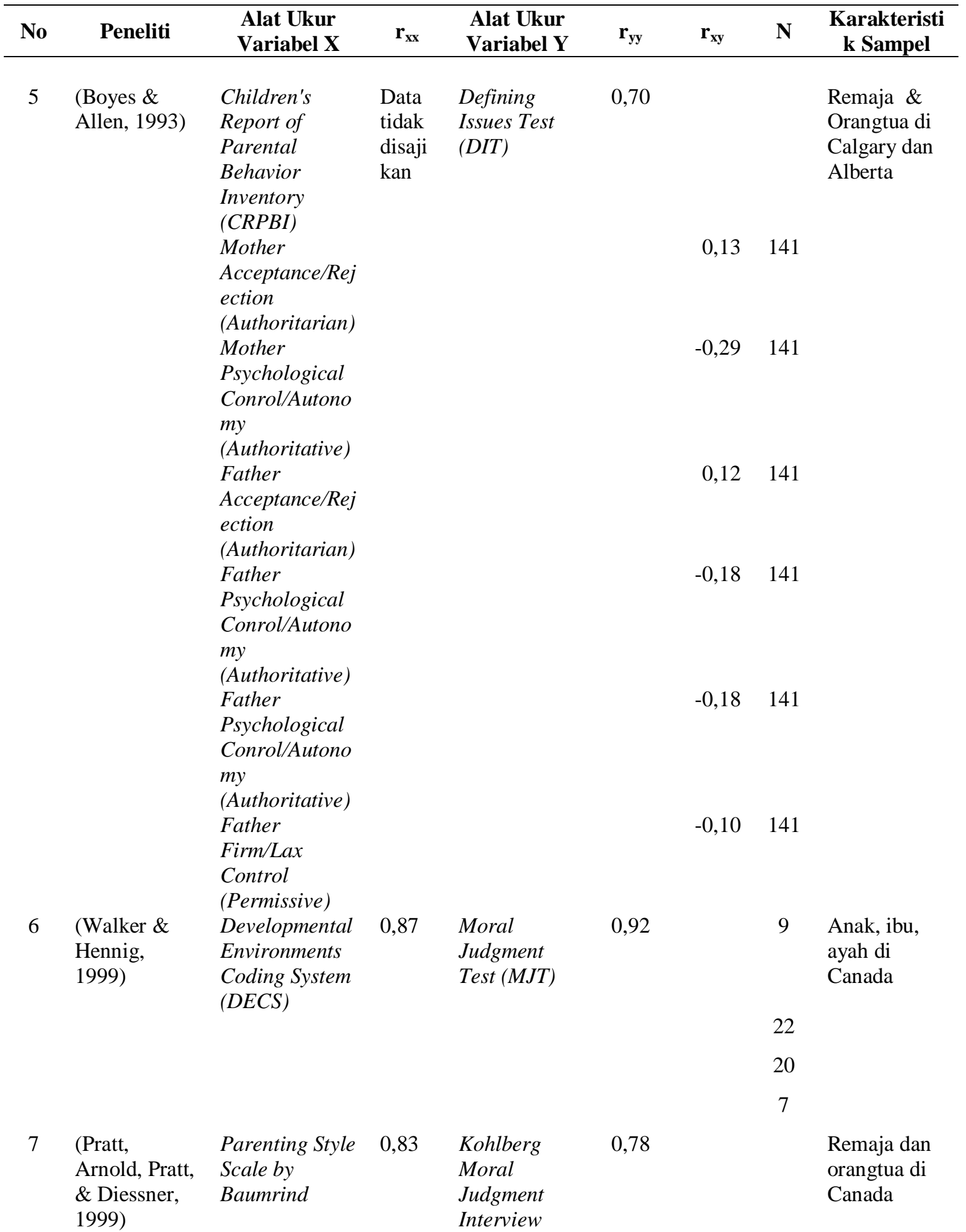


(Lanjutan) Tabel 1. Karkateristik Alat Ukur dan Contoh Penelitian

\begin{tabular}{|c|c|c|c|c|c|c|c|c|}
\hline No & Peneliti & $\begin{array}{c}\text { Alat Ukur } \\
\text { Variabel X }\end{array}$ & $\mathbf{r}_{\mathrm{xx}}$ & $\begin{array}{c}\text { Alat Ukur } \\
\text { Variabel Y }\end{array}$ & $\mathbf{r}_{\mathbf{y y}}$ & $\mathbf{r}_{\mathrm{xy}}$ & $\mathbf{N}$ & $\begin{array}{c}\text { Karakteristi } \\
\text { k Sampel }\end{array}$ \\
\hline \multirow[b]{4}{*}{8} & & Father (1) & & & & 0,28 & 40 & \\
\hline & & Mother (2) & & & & 0,2 & 40 & \\
\hline & & Father (2) & & & & 0,16 & 40 & \\
\hline & $\begin{array}{l}\text { (Walker, } \\
\text { Hennig, \& } \\
\text { Krettenauer, } \\
\text { 2000) }\end{array}$ & $\begin{array}{l}\text { Developmental } \\
\text { Environments } \\
\text { Coding System } \\
(\text { DECS })\end{array}$ & 0,85 & $\begin{array}{l}\text { Moral } \\
\text { Judgment } \\
\text { Test (MJT) }\end{array}$ & 0,84 & & 60 & $\begin{array}{l}\text { Remaja dan } \\
\text { orangtua di } \\
\text { Canada }\end{array}$ \\
\hline \multirow[t]{4}{*}{9} & $\begin{array}{l}\text { (Miners, } \\
\text { 2001) }\end{array}$ & $\begin{array}{l}\text { Parenting Style } \\
\text { Inventory III }\end{array}$ & & $\begin{array}{l}\text { Moral } \\
\text { Perspective } \\
\text { Questionnair } \\
e\end{array}$ & & & 120 & $\begin{array}{l}\text { Remaja di } \\
\text { Wilayah } \\
\text { Laurentians, } \\
\text { Southern, } \\
\text { Quebec }\end{array}$ \\
\hline & & Control & 0,74 & Precontional & 0,73 & & & \\
\hline & & Warmt & 0,78 & Conventional & 0,65 & & & \\
\hline & & $\begin{array}{l}\text { Psychological } \\
\text { Autonomy }\end{array}$ & 0,66 & & & & & \\
\hline \multirow[t]{9}{*}{10} & $\begin{array}{l}\text { (Vaden, } \\
\text { 2001) }\end{array}$ & $\begin{array}{l}\text { Parental } \\
\text { Authority } \\
\text { Questonnaire } \\
(P A Q)\end{array}$ & & $\begin{array}{l}\text { Defining } \\
\text { Issues Test } \\
(D I T)\end{array}$ & 0,77 & & 96 & $\begin{array}{l}\text { Remaja di } \\
\text { US }\end{array}$ \\
\hline & & $\begin{array}{l}\text { Mother's } \\
\text { Authoritarian }\end{array}$ & 0,85 & & & & & \\
\hline & & $\begin{array}{l}\text { Mother's } \\
\text { Authoritative }\end{array}$ & 0,82 & & & & & \\
\hline & & $\begin{array}{l}\text { Mother's } \\
\text { Permissive }\end{array}$ & 0,75 & & & & & \\
\hline & & $\begin{array}{l}\text { Father's } \\
\text { Authoritarian }\end{array}$ & 0,87 & & & & & \\
\hline & & $\begin{array}{l}\text { Father's } \\
\text { Authoritative }\end{array}$ & 0,85 & & & & & \\
\hline & & $\begin{array}{l}\text { Father's } \\
\text { Permissive }\end{array}$ & 0,74 & & & & & \\
\hline & & $\begin{array}{l}\text { Parental } \\
\text { Nurturance } \\
\text { Scale (PNS) } \\
\text { Mother }\end{array}$ & 0,95 & & & & & \\
\hline & & Father & 0,93 & & & & & \\
\hline
\end{tabular}


(Lanjutan) Tabel 1. Karkateristik Alat Ukur dan Contoh Penelitian

\begin{tabular}{|c|c|c|c|c|c|c|c|c|}
\hline No & Peneliti & $\begin{array}{l}\text { Alat Ukur } \\
\text { Variabel X }\end{array}$ & $\mathbf{r}_{\mathrm{xx}}$ & $\begin{array}{l}\text { Alat Ukur } \\
\text { Variabel Y }\end{array}$ & $\mathbf{r}_{\mathbf{y y}}$ & $\mathbf{r}_{\mathrm{xy}}$ & $\mathbf{N}$ & $\begin{array}{c}\text { Karakteristi } \\
\text { k Sampel }\end{array}$ \\
\hline & & Mother's & 0,87 & & & 0,02 & 302 & \\
\hline & & Authoritarian & & & & & & \\
\hline & & Mother's & 0,92 & & & $-0,03$ & 302 & \\
\hline & & Authoritative & & & & & & \\
\hline & & Mother's & 0,77 & & & $-0,01$ & 302 & \\
\hline & & Permissive & & & & & & \\
\hline & & Father's & & & & 0,06 & 302 & \\
\hline & & Authoritarian & & & & & & \\
\hline & & Father's & & & & $-0,06$ & 302 & \\
\hline & & Permissive & & & & & & \\
\hline & & Mother & $\begin{array}{l}0,92- \\
0,95\end{array}$ & & & $-0,06$ & 302 & \\
\hline & & Father & $0,93-$ & & & $-0,09$ & 302 & \\
\hline & & & 0,94 & & & & & \\
\hline \multirow[t]{8}{*}{12} & (Giunta, & Parental & & Defining & $0,70-$ & & 99 & Remaja dan \\
\hline & 2002) & $\begin{array}{l}\text { Authority } \\
\text { Questonnaire } \\
(P A Q)\end{array}$ & & $\begin{array}{l}\text { Issues Test } \\
(D I T)\end{array}$ & 0,80 & & & ibu di Florida \\
\hline & & Mother's & 0,85 & & & $-0,18$ & & \\
\hline & & Authoritarian & & & & & & \\
\hline & & Mother's & 0,82 & & & $-0,07$ & & \\
\hline & & Authoritative & & & & & & \\
\hline & & Mother's & 0,75 & & & $-0,01$ & & \\
\hline & & Permissive & & & & & & \\
\hline \multirow[t]{12}{*}{13} & (Jankowski, & Child's Report & & Defining & Data & & & Remaja (18- \\
\hline & 2002) & of Parent & & Issues Test & tidak & & & 22 th) di \\
\hline & & Behavior & & $(D I T)$ & disajik & & & Central New \\
\hline & & Inventory & & Version 2 & an & & & Jersey dan \\
\hline & & $(C R P B I)$ & & & & & & Nothern New \\
\hline & & shorter version & & & & & & York \\
\hline & & Mother & $\begin{array}{l}0,79- \\
0,84\end{array}$ & $\begin{array}{l}\text { Preconventio } \\
\text { nal }\end{array}$ & & $-0,35$ & 28 & \\
\hline & & & & Conventional & & 0,109 & 28 & \\
\hline & & & & $\begin{array}{l}\text { Postconventi } \\
\text { onal }\end{array}$ & & 0,202 & 28 & \\
\hline & & Father & $\begin{array}{l}0,83- \\
0,89\end{array}$ & $\begin{array}{l}\text { Preconventio } \\
\text { nal }\end{array}$ & & $-0,16$ & 28 & \\
\hline & & & & Conventional & & $-0,2$ & 28 & \\
\hline & & & & $\begin{array}{l}\text { Postconventi } \\
\text { onal }\end{array}$ & & 0,295 & 28 & \\
\hline \multirow[t]{4}{*}{14} & (Hawkins, & Parental & $0,77-$ & Defining & $0,70-$ & & 209 & \multirow{4}{*}{$\begin{array}{l}\text { Mahasiswa } \\
\text { di } \\
\text { Universitas } \\
\text { Liberti }\end{array}$} \\
\hline & 2005) & Authority & 0,92 & Issues Test & 0,80 & & & \\
\hline & & $\begin{array}{l}\text { Questionnaire } \\
(P A Q)\end{array}$ & & $(D I T)$ & & & & \\
\hline & & Authoritarian & & & & 0,159 & 209 & \\
\hline
\end{tabular}


(Lanjutan) Tabel 1. Karkateristik Alat Ukur dan Contoh Penelitian

\begin{tabular}{|c|c|c|c|c|c|c|c|c|}
\hline No & Peneliti & $\begin{array}{c}\text { Alat Ukur } \\
\text { Variabel X }\end{array}$ & $\mathbf{r}_{\mathrm{xx}}$ & $\begin{array}{c}\text { Alat Ukur } \\
\text { Variabel Y }\end{array}$ & $\mathbf{r}_{\mathbf{y y}}$ & $\mathbf{r}_{\mathrm{xy}}$ & $\mathbf{N}$ & $\begin{array}{c}\text { Karakteristi } \\
\text { k Sampel }\end{array}$ \\
\hline & & Permissive & & & & $-0,12$ & 209 & \\
\hline & & $\begin{array}{l}\text { Mother } \\
\text { Warmth }\end{array}$ & 0,7 & & & $-0,01$ & 730 & \\
\hline & & $\begin{array}{l}\text { Mother Strict } \\
\text { Control }\end{array}$ & 0,61 & & & $-0,03$ & 730 & \\
\hline & & Father Warmth & 0,79 & & & 0,01 & 730 & \\
\hline & & $\begin{array}{l}\text { Father Strict } \\
\text { Control }\end{array}$ & 0,63 & & & $-0,02$ & 730 & \\
\hline & & $\begin{array}{l}\text { Mother } \\
\text { Warmth }\end{array}$ & 0,76 & & & 0,09 & 730 & \\
\hline & & $\begin{array}{l}\text { Mother Strict } \\
\text { Control }\end{array}$ & 0,62 & & & $-0,02$ & 730 & \\
\hline & & Father Warmth & 0,81 & & & 0,12 & 730 & \\
\hline & & $\begin{array}{l}\text { Father Strict } \\
\text { Control }\end{array}$ & 0,65 & & & 0,01 & 730 & \\
\hline & & $\begin{array}{l}\text { Mother } \\
\text { Warmth }\end{array}$ & 0,75 & & & 0,1 & 730 & \\
\hline & & $\begin{array}{l}\text { Mother Strict } \\
\text { Control }\end{array}$ & 0,61 & & & 0,08 & 730 & \\
\hline & & Father Warmth & 0,79 & & & 0,08 & 730 & \\
\hline & & $\begin{array}{l}\text { Father Strict } \\
\text { Control }\end{array}$ & 0,61 & & & 0,09 & 730 & \\
\hline \multirow[t]{4}{*}{16} & $\begin{array}{l}\text { (Abad, } \\
\text { Taheri, \& } \\
\text { Yakhdani, } \\
\text { 2013) }\end{array}$ & $\begin{array}{l}\text { Baumrind's } \\
\text { Pareting Style } \\
\text { Questionnaire }\end{array}$ & $\begin{array}{l}\text { Data } \\
\text { tidak } \\
\text { disaji } \\
\text { kan }\end{array}$ & $\begin{array}{l}\text { Kohlberg } \\
\text { Moral } \\
\text { Development } \\
\text { Questionnar } \\
e\end{array}$ & $\begin{array}{c}\text { Data } \\
\text { tidak } \\
\text { disajik } \\
\text { an }\end{array}$ & & & $\begin{array}{l}\text { Anak dan } \\
\text { orangtua di } \\
\text { Kota Yazd, } \\
\text { Iran }\end{array}$ \\
\hline & & Authoritarian & & & & $-0,04$ & 120 & \\
\hline & & Authoritative & & & & 0,48 & 120 & \\
\hline & & Indulgent & & & & $-0,09$ & 120 & \\
\hline 17 & $\begin{array}{l}\text { (Seydoogulla } \\
\text { ri, Aridag, \& } \\
\text { Koc, 2014) }\end{array}$ & $\begin{array}{l}\text { Parental } \\
\text { Attitude Scale }\end{array}$ & $\begin{array}{l}\text { Data } \\
\text { tidak } \\
\text { disaji } \\
\text { kan }\end{array}$ & $\begin{array}{l}\text { Moral } \\
\text { Judgment } \\
\text { Test of Lind }\end{array}$ & $\begin{array}{c}\text { Data } \\
\text { tidak } \\
\text { disajik } \\
\text { an }\end{array}$ & & 419 & $\begin{array}{l}\text { Siswa } \\
\text { Menengah di } \\
\text { Kocaeli, } \\
\text { Istambul }\end{array}$ \\
\hline \multirow[t]{2}{*}{18} & $\begin{array}{l}\text { (Yuniarrahm } \\
\text { ah \& } \\
\text { Rachmah, } \\
\text { 2014) }\end{array}$ & $\begin{array}{l}\text { Skala Pola } \\
\text { Asuh }\end{array}$ & 0,81 & $\begin{array}{l}\text { Skala } \\
\text { Penalaran } \\
\text { Moral }\end{array}$ & 0,526 & & 253 & $\begin{array}{l}\text { Remaja di } \\
\text { Banjarmasin }\end{array}$ \\
\hline & & $\begin{array}{l}\text { Pola Asuh } \\
\text { Otoritatif } \\
\text { Pola Asuh } \\
\text { Otoritarian }\end{array}$ & $\begin{array}{l}0,645 \\
0,768\end{array}$ & & & & & \\
\hline
\end{tabular}


(Lanjutan) Tabel 1. Karkateristik Alat Ukur dan Contoh Penelitian

\begin{tabular}{|c|c|c|c|c|c|c|c|c|}
\hline No & Peneliti & $\begin{array}{c}\text { Alat Ukur } \\
\text { Variabel X }\end{array}$ & $\mathbf{r}_{\mathrm{xx}}$ & $\begin{array}{c}\text { Alat Ukur } \\
\text { Variabel Y }\end{array}$ & $\mathbf{r}_{\mathrm{yy}}$ & $\mathbf{r}_{\mathrm{xy}}$ & $\mathbf{N}$ & $\begin{array}{c}\text { Karakteristi } \\
\text { k Sampel }\end{array}$ \\
\hline 19 & $\begin{array}{l}\text { (Loudova \& } \\
\text { Lasek, 2015) }\end{array}$ & $\begin{array}{l}\text { The Inventory } \\
\text { of Parental } \\
\text { Behavior }\end{array}$ & 0,91 & $\begin{array}{l}\text { Moral } \\
\text { Dilemma } \\
\text { Questionnair } \\
e\end{array}$ & 0,85 & & 431 & $\begin{array}{l}\text { Remaja di } \\
\text { California }\end{array}$ \\
\hline 20 & $\begin{array}{l}\text { (Kumari \& } \\
\text { Khanna, } \\
\text { 2016) }\end{array}$ & $\begin{array}{l}\text { Parental } \\
\text { Authority } \\
\text { Questonnaire } \\
\text { (PAQ) } \\
\text { Authoritarian }\end{array}$ & $\begin{array}{l}\text { Data } \\
\text { tidak } \\
\text { disaji } \\
\text { kan }\end{array}$ & $\begin{array}{l}\text { Moral } \\
\text { Judgment } \\
\text { Test }(M J T)\end{array}$ & & $-0,05$ & 100 & $\begin{array}{l}\text { Remaja di } \\
\text { Newai, Tonk } \\
\text { (Rajasthan) }\end{array}$ \\
\hline & & Authoritative & & & & 0,065 & & \\
\hline & & Permissive & & & & 0.03 & & \\
\hline
\end{tabular}

Keterangan: $r_{\mathrm{xx}}=$ koefisien reliabilitas alat ukur variabel $\mathrm{X} ; \mathrm{r}_{\mathrm{yy}}=$ koefisien reliabilitas alat ukur variabel $\mathrm{Y} ; \mathrm{r}_{\mathrm{xy}}=$ koefisien korelasi variabel $\mathrm{X}$ dan $\mathrm{Y} ; \mathrm{N}=$ jumlah contoh penelitian

Kriteria artikel untuk penelitian ini adalah (1) studi primer dalam setting penelitian korelasional, komparasi atau eksperimen tentang apapun perlakuan yang diberikan (bisa berupa pemberian kuesioner atau terapi tertentu dan jeda waktu); (2) dipublikasikan dalam semua bahasa ; (3) artikel merupakan artikel lengkap yang dipublikasikan secara daring (online); (4) memiliki informasi statistik yang diperlukan seperti nilai rerata, standar deviasi, nilai r, maupun nilai F; (5) contoh-contoh penelitian dapat melibatkan orang tua dan remaja atau orang tua saja atau remaja saja; (6) variabel pengasuhan orangtua dapat diukur dari penilaian orang tua, penilaian remaja, atau penilaian keduanya. (7) variabel penalaran dapat dikur dari orang tua maupun remaja. Berdasarkan pemenuhan kriteria di atas, maka dari 34 artikel yang terkumpul, hanya ada 20 artikel yang digunakan untuk kajian meta-analisis ini. Studi yang dilakukan sebagian menggunakan teknik cross sectional, sequential, dan longitudinal, sehingga menghasilkan jumlah studi yang cukup banyak. Berdasarkan 20 artikel tersebut dihasilkan 72 studi yang meneliti peran pengasuhan orangtua dengan penalaran moral.

Tabel 2. Transformansi Nilai F, t, d, r

\begin{tabular}{lccccccc}
\hline Peneliti & No Studi & $\mathbf{N}$ & $\mathbf{F}$ & $\mathbf{t}$ & $\mathbf{d}$ & $\mathbf{r}_{\mathbf{x y}}$ & $\mathbf{p}$ \\
\hline (Kiitredge, 1984) & 1 & 26 & 2.23 & 1,49 & 0,59 & 0,28 & $\mathrm{p}>0.05$ \\
(Hart, 1988) & 2 & 10 & & & & $-0,15$ & $\mathrm{p}>0.05$ \\
& 3 & 18 & & & & 0,09 & $\mathrm{p}>0.05$ \\
& 4 & 15 & & & & 0,37 & $\mathrm{p}>0.05$
\end{tabular}




\begin{tabular}{|c|c|c|c|c|c|c|c|}
\hline & 5 & 13 & & & & $-0,18$ & $\mathrm{p}>0.05$ \\
\hline & 6 & 12 & & & & 0,39 & $\mathrm{p}>0.05$ \\
\hline & 7 & 12 & & & & 0,31 & $\mathrm{p}>0.05$ \\
\hline & 8 & 7 & & & & 0,79 & $\mathrm{p}<0.05$ \\
\hline & 9 & 12 & & & & 0,56 & $\mathrm{p}<0.05$ \\
\hline & 10 & 9 & & & & 0,66 & $\mathrm{p}<0.05$ \\
\hline & 11 & 9 & & & & 0,48 & $\mathrm{p}>0.05$ \\
\hline & 12 & 9 & & & & 0,74 & $\mathrm{p}<0.05$ \\
\hline & 13 & 7 & & & & $-0,07$ & $\mathrm{p}>0.05$ \\
\hline (Walker \& Taylor, 1991) & 14 & 63 & 4,54 & 0,3 & 0,08 & 0,04 & $\mathrm{p}<0.01$ \\
\hline \multirow[t]{4}{*}{ (Speicher, 1992) } & 15 & 92 & & & & 0,44 & $\mathrm{p}<0.01$ \\
\hline & 16 & 92 & & & & 0,48 & $\mathrm{p}<0.01$ \\
\hline & 17 & 92 & & & & 0,64 & $\mathrm{p}<0.01$ \\
\hline & 18 & 92 & & & & 0,36 & $\mathrm{p}<0.05$ \\
\hline \multirow[t]{6}{*}{ (Boyes \& Allen, 1993) } & 19 & 141 & & & & 0,13 & $\mathrm{p}>0.05$ \\
\hline & 20 & 141 & & & & $-0,29$ & $\mathrm{p}<0.01$ \\
\hline & 21 & 141 & & & & $-0,23$ & $\mathrm{p}<0.05$ \\
\hline & 22 & 141 & & & & 0,12 & $\mathrm{p}>0.05$ \\
\hline & 23 & 141 & & & & $-0,18$ & $\mathrm{p}>0.05$ \\
\hline & 24 & 141 & & & & $-0,10$ & $\mathrm{p}>0.05$ \\
\hline \multirow[t]{4}{*}{$\begin{array}{l}\text { (Walker \& Hennig, } \\
\text { 1999) }\end{array}$} & 25 & 9 & & 0,16 & 0,11 & 0,05 & $\mathrm{p}<0.05$ \\
\hline & 26 & 22 & & 0,38 & 0,16 & 0,08 & $\mathrm{p}<0.05$ \\
\hline & 27 & 20 & & 0,72 & 0,32 & 0,16 & $\mathrm{p}<0.05$ \\
\hline & 28 & 7 & & 0,81 & 0,61 & 0,29 & $\mathrm{p}<0.05$ \\
\hline \multirow[t]{4}{*}{ (Pratt et al., 1999) } & 29 & 40 & & & & 0,28 & $\mathrm{p}<0.05$ \\
\hline & 30 & 40 & & & & 0,28 & $\mathrm{p}<0.05$ \\
\hline & 31 & 40 & & & & 0,2 & $\mathrm{p}<0.05$ \\
\hline & 32 & 40 & & & & 0,16 & $\mathrm{p}<0.05$ \\
\hline (Walker et al., 2000) & 33 & 60 & 2,232 & 1,49 & 0,39 & 0,19 & $\mathrm{p}<0.01$ \\
\hline (Miners, 2001) & 34 & 120 & 3,92 & 1,98 & 0,36 & 0,18 & $\mathrm{p}<0.01$ \\
\hline (Vaden, 2001) & 35 & 96 & 10,507 & 3,24 & 0,66 & 0,31 & $\mathrm{p}<0.01$ \\
\hline \multirow[t]{8}{*}{ (Lee, 2001) } & 36 & 302 & & & & 0,02 & $\mathrm{p}>0.05$ \\
\hline & 37 & 302 & & & & $-0,03$ & $\mathrm{p}>0.05$ \\
\hline & 38 & 302 & & & & $-0,01$ & $\mathrm{p}>0.05$ \\
\hline & 39 & 302 & & & & 0,06 & $\mathrm{p}>0.05$ \\
\hline & 40 & 302 & & & & $-0,01$ & $\mathrm{p}>0.05$ \\
\hline & 41 & 302 & & & & $-0,06$ & $\mathrm{p}>0.05$ \\
\hline & 42 & 302 & & & & $-0,06$ & $\mathrm{p}>0.05$ \\
\hline & 43 & 302 & & & & $-0,09$ & $\mathrm{p}>0.05$ \\
\hline \multirow[t]{3}{*}{ (Giunta, 2002) } & 44 & 99 & & & & $-0,179$ & $\mathrm{p}>0.05$ \\
\hline & 45 & 99 & & & & $-0,07$ & $\mathrm{p}>0.05$ \\
\hline & 46 & 99 & & & & $-0,007$ & $\mathrm{p}>0.05$ \\
\hline \multirow[t]{6}{*}{ (Jankowski, 2002) } & 47 & 28 & & & & $-0,354$ & $\mathrm{p}>0.05$ \\
\hline & 48 & 28 & & & & 0,109 & $\mathrm{p}>0.05$ \\
\hline & 49 & 28 & & & & 0,202 & $\mathrm{p}>0.05$ \\
\hline & 50 & 28 & & & & $-0,163$ & $p>0.05$ \\
\hline & 51 & 28 & & & & $-0,195$ & $\mathrm{p}>0.05$ \\
\hline & 52 & 28 & & & & 0,295 & $\mathrm{p}>0.05$ \\
\hline (Hawkins, 2005) & 53 & 209 & 3,049 & 1,75 & 0,24 & 0,012 & $\mathrm{p}<0.05$ \\
\hline
\end{tabular}




\begin{tabular}{|c|c|c|c|c|c|c|c|}
\hline \multirow[t]{12}{*}{ (Carlo et al., 2011) } & 54 & 730 & & & & $-0,01$ & $\mathrm{p}>0.05$ \\
\hline & 55 & 730 & & & & $-0,03$ & $\mathrm{p}>0.05$ \\
\hline & 56 & 730 & & & & 0,01 & $\mathrm{p}>0.05$ \\
\hline & 57 & 730 & & & & $-0,02$ & $\mathrm{p}>0.05$ \\
\hline & 58 & 730 & & & & 0,09 & $\mathrm{p}<0.05$ \\
\hline & 59 & 730 & & & & $-0,02$ & $\mathrm{p}>0.05$ \\
\hline & 60 & 730 & & & & 0,12 & $\mathrm{p}<0.05$ \\
\hline & 61 & 730 & & & & 0,01 & $\mathrm{p}>0.05$ \\
\hline & 62 & 730 & & & & 0,1 & $\mathrm{p}<0.05$ \\
\hline & 63 & 730 & & & & 0,08 & $\mathrm{p}<0.05$ \\
\hline & 64 & 730 & & & & 0,08 & $\mathrm{p}<0.05$ \\
\hline & 65 & 730 & & & & 0,09 & $\mathrm{p}<0.05$ \\
\hline \multirow[t]{3}{*}{ (Abad et al., 2013) } & 66 & 120 & & & & $-0,04$ & $\mathrm{p}>0.05$ \\
\hline & 67 & 120 & & & & 0,48 & $\mathrm{p}<0.01$ \\
\hline & 68 & 120 & & & & $-0,09$ & $\mathrm{p}>0.05$ \\
\hline $\begin{array}{l}\text { (Seydoogullari et al., } \\
\text { 2014) }\end{array}$ & 69 & 419 & & 0,302 & 0,03 & 0,01 & $\mathrm{p}>0.05$ \\
\hline $\begin{array}{l}\text { (Yuniarrahmah \& } \\
\text { Rachmah, 2014) }\end{array}$ & 70 & 253 & 1,798 & 1,34 & 0,17 & 0,08 & $\mathrm{p}>0.05$ \\
\hline $\begin{array}{l}\text { (Loudová \& Lašek, } \\
\text { 2015) }\end{array}$ & 71 & 431 & 8,34 & 2,89 & 0,23 & 0,14 & $\mathrm{p}<0.05$ \\
\hline $\begin{array}{l}\text { (Kumari \& Khanna, } \\
\text { 2016) }\end{array}$ & 72 & 100 & & & & $-0,015$ & $\mathrm{p}>0.05$ \\
\hline
\end{tabular}

Keterangan: $\mathrm{n}=$ jumlah contoh dalam studi; $\mathrm{F}=$ Nilai $\mathrm{F}$; $\mathrm{t}=$ nilai $\mathrm{t}$; $\mathrm{d}=$ nilai $\mathrm{d}$; $\mathrm{rxy}=$ koefisien korelasi variabel $\mathrm{X}$ dan $\mathrm{Y}$; $\mathrm{p}=$ signifikansi korelasi.

Tabel 3. Data Korelasi Pengasuhan dengan Penalaran Moral

\begin{tabular}{|c|c|c|c|c|c|c|c|}
\hline No Studi & $\mathrm{N}$ & ri & $\mathrm{Nr}$ & $\check{\mathrm{r}}$ & (ri-řr) & $(\mathrm{ri}-\check{\mathrm{r}})^{2}$ & $\mathrm{~N}(\mathrm{ri}-\check{\mathrm{r}})^{2}$ \\
\hline 1 & 26 & 0,28 & 7,28 & 0,04 & 0,24 & 0,0576 & 1,4976 \\
\hline 2 & 10 & $-0,15$ & $-1,50$ & 0,04 & $-0,19$ & 0,0361 & 0,361 \\
\hline 3 & 18 & 0,09 & 1,62 & 0,04 & 0,05 & 0,0025 & 0,045 \\
\hline 4 & 15 & 0,37 & 5,55 & 0,04 & 0,33 & 0,1089 & 1,6335 \\
\hline 5 & 13 & $-0,18$ & $-2,34$ & 0,04 & $-0,22$ & 0,0484 & 0,6292 \\
\hline 6 & 12 & 0,39 & 4,68 & 0,04 & 0,35 & 0,1225 & 1,47 \\
\hline 7 & 12 & 0,31 & 3,72 & 0,04 & 0,27 & 0,0729 & 0,8748 \\
\hline 8 & 7 & 0,79 & 5,53 & 0,04 & 0,75 & 0,5625 & 3,9375 \\
\hline 9 & 12 & 0,56 & 6,72 & 0,04 & 0,52 & 0,2704 & 3,2448 \\
\hline 10 & 9 & 0,66 & 5,94 & 0,04 & 0,62 & 0,3844 & 3,4596 \\
\hline 11 & 9 & 0,48 & 4,32 & 0,04 & 0,44 & 0,1936 & 1,7424 \\
\hline 12 & 9 & 0,74 & 6,66 & 0,04 & 0,7 & 0,49 & 4,41 \\
\hline 13 & 7 & $-0,07$ & $-0,49$ & 0,04 & $-0,11$ & 0,0121 & 0,0847 \\
\hline 14 & 63 & 0,04 & 2,52 & 0,04 & 0 & 0 & 0 \\
\hline 15 & 92 & 0,44 & 40,48 & 0,04 & 0,4 & 0,16 & 14,72 \\
\hline 16 & 92 & 0,48 & 44,16 & 0,04 & 0,44 & 0,1936 & 17,8112 \\
\hline 17 & 92 & 0,64 & 58,88 & 0,04 & 0,6 & 0,36 & 33,12 \\
\hline
\end{tabular}




\begin{tabular}{|c|c|c|c|c|c|c|c|}
\hline 18 & 92 & 0,36 & 33,12 & 0,04 & 0,32 & 0,1024 & 9,4208 \\
\hline 19 & 141 & 0,13 & 18,33 & 0,04 & 0,09 & 0,0081 & 1,1421 \\
\hline 20 & 141 & $-0,29$ & $-40,89$ & 0,04 & $-0,33$ & 0,1089 & 15,3549 \\
\hline 21 & 141 & $-0,23$ & $-32,43$ & 0,04 & $-0,27$ & 0,0729 & 10,2789 \\
\hline 22 & 141 & 0,12 & 16,92 & 0,04 & 0,08 & 0,0064 & 0,9024 \\
\hline 23 & 141 & $-0,18$ & $-25,38$ & 0,04 & $-0,22$ & 0,0484 & 6,8244 \\
\hline 24 & 141 & $-0,10$ & $-14,10$ & 0,04 & $-0,14$ & 0,0196 & 2,7636 \\
\hline 25 & 9 & 0,05 & 0,45 & 0,04 & 0,01 & 0,0001 & 0,0009 \\
\hline 26 & 22 & 0,08 & 1,76 & 0,04 & 0,04 & 0,0016 & 0,0352 \\
\hline 27 & 20 & 0,16 & 3,20 & 0,04 & 0,12 & 0,0144 & 0,288 \\
\hline 28 & 7 & 0,29 & 2,03 & 0,04 & 0,25 & 0,0625 & 0,4375 \\
\hline 29 & 40 & 0,28 & 11,20 & 0,04 & 0,24 & 0,0576 & 2,304 \\
\hline 30 & 40 & 0,28 & 11,20 & 0,04 & 0,24 & 0,0576 & 2,304 \\
\hline 31 & 40 & 0,2 & 8,00 & 0,04 & 0,16 & 0,0256 & 1,024 \\
\hline 32 & 40 & 0,16 & 6,40 & 0,04 & 0,12 & 0,0144 & 0,576 \\
\hline 33 & 60 & 0,19 & 11,40 & 0,04 & 0,15 & 0,0225 & 1,35 \\
\hline 34 & 120 & 0,18 & 21,60 & 0,04 & 0,14 & 0,0196 & 2,352 \\
\hline 35 & 96 & 0,31 & 29,76 & 0,04 & 0,27 & 0,0729 & 6,9984 \\
\hline 36 & 302 & 0,02 & 6,04 & 0,04 & $-0,02$ & 0,0004 & 0,1208 \\
\hline 37 & 302 & $-0,03$ & $-9,06$ & 0,04 & $-0,07$ & 0,0049 & 1,4798 \\
\hline 38 & 302 & $-0,01$ & $-3,02$ & 0,04 & $-0,05$ & 0,0025 & 0,755 \\
\hline 39 & 302 & 0,06 & 18,12 & 0,04 & 0,02 & 0,0004 & 0,1208 \\
\hline 40 & 302 & $-0,01$ & $-3,02$ & 0,04 & $-0,05$ & 0,0025 & 0,755 \\
\hline 41 & 302 & $-0,06$ & $-18,12$ & 0,04 & $-0,1$ & 0,01 & 3,02 \\
\hline 42 & 302 & $-0,06$ & $-18,12$ & 0,04 & $-0,1$ & 0,01 & 3,02 \\
\hline 43 & 302 & $-0,09$ & $-27,18$ & 0,04 & $-0,13$ & 0,0169 & 5,1038 \\
\hline 44 & 99 & $-0,179$ & $-17,72$ & 0,04 & $-0,219$ & 0,047961 & 4,748139 \\
\hline 45 & 99 & $-0,07$ & $-6,93$ & 0,04 & $-0,11$ & 0,0121 & 1,1979 \\
\hline 46 & 99 & $-0,007$ & $-0,69$ & 0,04 & $-0,047$ & 0,002209 & 0,218691 \\
\hline 47 & 28 & $-0,354$ & $-9,91$ & 0,04 & $-0,394$ & 0,155236 & 4,346608 \\
\hline 48 & 28 & 0,109 & 3,05 & 0,04 & 0,069 & 0,004761 & 0,133308 \\
\hline 49 & 28 & 0,202 & 5,66 & 0,04 & 0,162 & 0,026244 & 0,734832 \\
\hline 50 & 28 & $-0,163$ & $-4,56$ & 0,04 & $-0,203$ & 0,041209 & 1,153852 \\
\hline 51 & 28 & $-0,195$ & $-5,46$ & 0,04 & $-0,235$ & 0,055225 & 1,5463 \\
\hline 52 & 28 & 0,295 & 8,26 & 0,04 & 0,255 & 0,065025 & 1,8207 \\
\hline 53 & 209 & 0,012 & 2,51 & 0,04 & $-0,028$ & 0,000784 & 0,163856 \\
\hline 54 & 730 & $-0,01$ & $-7,30$ & 0,04 & $-0,05$ & 0,0025 & 1,825 \\
\hline 55 & 730 & $-0,03$ & $-21,90$ & 0,04 & $-0,07$ & 0,0049 & 3,577 \\
\hline 56 & 730 & 0,01 & 7,30 & 0,04 & $-0,03$ & 0,0009 & 0,657 \\
\hline 57 & 730 & $-0,02$ & $-14,60$ & 0,04 & $-0,06$ & 0,0036 & 2,628 \\
\hline
\end{tabular}




\begin{tabular}{rrrrrrrr}
58 & 730 & 0,09 & 65,70 & 0,04 & 0,05 & 0,0025 & 1,825 \\
59 & 730 & $-0,02$ & $-14,60$ & 0,04 & $-0,06$ & 0,0036 & 2,628 \\
60 & 730 & 0,12 & 87,60 & 0,04 & 0,08 & 0,0064 & 4,672 \\
61 & 730 & 0,01 & 7,30 & 0,04 & $-0,03$ & 0,0009 & 0,657 \\
62 & 730 & 0,1 & 73,00 & 0,04 & 0,06 & 0,0036 & 2,628 \\
63 & 730 & 0,08 & 58,40 & 0,04 & 0,04 & 0,0016 & 1,168 \\
64 & 730 & 0,08 & 58,40 & 0,04 & 0,04 & 0,0016 & 1,168 \\
65 & 730 & 0,09 & 65,70 & 0,04 & 0,05 & 0,0025 & 1,825 \\
66 & 120 & $-0,04$ & $-4,80$ & 0,04 & $-0,08$ & 0,0064 & 0,768 \\
67 & 120 & 0,48 & 57,60 & 0,04 & 0,44 & 0,1936 & 23,232 \\
68 & 120 & $-0,09$ & $-10,80$ & 0,04 & $-0,13$ & 0,0169 & 2,028 \\
69 & 419 & 0,01 & 4,19 & 0,04 & $-0,03$ & 0,0009 & 0,3771 \\
70 & 253 & 0,08 & 20,24 & 0,04 & 0,04 & 0,0016 & 0,4048 \\
71 & 431 & 0,14 & 60,34 & 0,04 & 0,1 & 0,01 & 4,31 \\
72 & 100 & $-0,015$ & $-1,50$ & 0,04 & $-0,055$ & 0,003025 & 0,3025 \\
\hline Jumlah & 15343 & & 666,41 & & & & 240,518186 \\
\hline Rerata & & & 0,12 & & & \\
\hline
\end{tabular}

\section{Koreksi Kesalahan Pengambilan Contoh (Bare Bone Meta-analysis)}

Apabila korelasi pada populasi dianggap tetap atau konstan diantara beberapa studi, maka estimasi terbaik dari korelasi bukan rerata sederhana yang diperoleh dari korelasi beberapa studi melainkan merupakan rerata yang dibobot untuk masing-masing korelasi yaitu dibagi dengan jumlah contoh dalam studi (Hunter \& Schmidt, 2004). Hasil perhitungan menunjukkan bahwa total N.r $\mathrm{r}_{\mathrm{xy}}$ $=666,406$. Rerata korelasi populasi yang sesungguhnya setelah dikoreksi dengan kesalahan pengambilan contoh adalah sebesar 0,04, varian $r_{x y}$ atau $\sigma_{r}^{2}=0,01568$, standar deviasi (SD) sebesar 0,24, varian kesalahan pengambilan contoh sebesar 0,0047, dan variansi korelasi populasi atau varians yang sesungguhnya sebesar 0,01098. Berdasarkan pengolahan data primer, terdapat 31 studi dari 72 studi (43,06 persen)yang mempunyai nilai korelasi di bawah rerata korelasi populasi (studi 2, 5, 13, 20, 21, 23, 24, 36, 37, 38, 40, 41, 42, 43, 44, 45, 46,47, 50, 51, 53, $54,55,56,57,59,61,66,68,69$, dan 72$)$ dan 41 studi dari 72 studi (56,94 persen) di atas nilai rerata korelasi populasi (studi 1, 3, 4, 6, 7, 8, 9, 10, 11, 12, 14, 15, 16, $17,18,19,22,25,26,27,28,29,30,31,32,33,34,35,39,48,49,52,58,60,62$, $63,64,65,67,70$, dan 71). Hipotesis yang menyatakan bahwa pengasuhan 
orangtua memiliki hubungan dengan penalaran moral pada remaja dapat diterima, berdasarkan pertimbangan dari interval kepercayaan 95 persen diperoleh rentang penerimaan mulai dari -0,2056 sampai dengan 0,2856. Varian yang disebabkan oleh kesalahan pengambilan contoh adalah 29,97 persen dan disebabkan faktor lain adalah 70,03 persen. Rendahnya korelasi antara pengasuhan dengan penalaran moral dimungkinkan adanya varabel lain yang lebih berpengaruh terhadap penalaran moral.

Selanjutnya peneliti melakukan koreksi kesalahan pengambilan contoh/ bare bones meta-analysis dengan mengelompokkan studi berdasarkan jenis gaya pengasuhan yaitu sembilan artikel dengan 46 studi. Sembilan artikel tersebut adalah yang ditulis oleh Boyers \& Allen, 1993; Pratt, et al.,1999; Miners, 2001; Lee, 2001; Giunta, 2002; Hawkins, 2005; Carlo et al, 2010. Adapun hasil perhitungan bare bone meta-analysis dapat dilihat pada Tabel 4.

Tabel 4. Hasil Koreksi Kesalahan Pengambilan Contoh Untuk Tiga Jenis Gaya Pengasuhan

\begin{tabular}{lccc}
\hline & Otoritatif & Otoritarian & Permisif \\
\hline Rerata korelasi populasi & 0,046 & 0,015 & $-0,038$ \\
Varians korelasi populasi & 0,012 & 0,0034 & 0,0112 \\
$\begin{array}{l}\text { Varians kesalahan pengambilan } \\
\text { sampel }\end{array}$ & 0,0029 & 0,003 & 0,0061 \\
$\begin{array}{l}\text { Varians korelasi populasi } \\
\text { sesungguhnya }\end{array}$ & 0,0091 & 0,0004 & 0,0051 \\
$\begin{array}{l}\text { Standar deviasi korelasi } \\
\text { populasi }\end{array}$ & 0,1095 & 0,0583 & 0,1058 \\
$\begin{array}{l}\text { Interval kepercayaan } \\
\begin{array}{l}\text { Dampak kesalahan } \\
\text { pengambilan sampel }\end{array}\end{array}$ & $-0,1647-0,2647$ & $-0,0995-0,1291$ & $-0,2454-0,1694$ \\
& $24,17 \%$ & $88,24 \%$ & $54,46 \%$ \\
\hline
\end{tabular}

Berdasarkan hasil perhitungan pada Tabel 4 diketahui bahwa masingmasing dari ketiga gaya pengasuhan otoritatif, otoritarian, dan permisif memiliki hubungan dengan penalaran moral. Gaya pengasuhan otoritatif memiliki ř terbesar diantara gaya pengasuhan yang lain yaitu 0,046 dengan dampak kesalahan pengambilan contoh sebesar 24,17 persen berarti ada sekitar 75,83 persen ada faktor kesalahan lain yang belum dapat diidentifikasikan. Jenis gaya pengasuhan orangtua ini kemungkinan dapat menjadi variabel moderator. Menurut pendapat Hunter \& Schmidt (2004), korelasi yang diperoleh bervariasi tergantung dari pengelompokkan yang diukur. Hasil penelitian lain yang menguatkan menemukan 
bahwa pengasuhan orangtua baik bapak atau ibu yang ditunjukkan dengan sikap yang hangat atau kontrol yang sifatnya kaku dapat memengaruhi penalaran moral pada anak usia remaja awal (Carlo et al., 2011). Orangtua yang hangat akan memberi kesempatan pada anak untuk menyampaikan pendapat dan ada komunikasi yang baik dengan anak. Sedangkan orangtua yang terlalu kaku cenderung tidak memberi kesempatan anak untuk bicara dan belajar sehingga dapat menghambat kemampuan penalaran moral.

\section{Koreksi Kesalahan Pengukuran}

Koreksi terhadap artefak selain kesalahan pengambilan contoh adalah koreksi kesalahan pengukuran. Pada studi yang berkaitan dengan keterkaitan antara pengasuhan dan penalaran moral yang digunakan dalam meta-analisis ini, semuanya merupakan studi dengan pendekatan survey. Untuk membuat estimasi kesalahan pengukuran, maka disusun lembar kerja seperti pada Tabel 5 berikut ini:

Tabel 5. Lembar Kerja Estimasi Pengukuran

\begin{tabular}{ccccccc}
\hline No Studi & $\mathbf{N}$ & $\boldsymbol{r}_{\boldsymbol{x} y}$ & $\boldsymbol{r}_{\boldsymbol{x}}$ & $\boldsymbol{a}$ & $\boldsymbol{r}_{\boldsymbol{y}}$ & $\boldsymbol{b}$ \\
\hline 1 & 26 & 0,28 & - & - & 0,81 & 0,900 \\
2 & 10 & $-0,15$ & - & - & 0,98 & 0,990 \\
3 & 18 & 0,09 & - & - & - & - \\
4 & 15 & 0,37 & - & - & - & - \\
5 & 13 & $-0,18$ & - & - & - & - \\
6 & 12 & 0,39 & - & - & - & - \\
7 & 12 & 0,31 & - & - & - & - \\
8 & 7 & 0,79 & - & - & - & - \\
9 & 12 & 0,56 & - & - & - & - \\
10 & 9 & 0,66 & - & - & - & - \\
11 & 9 & 0,48 & - & - & - & - \\
12 & 9 & 0,74 & - & - & - & - \\
13 & 7 & $-0,07$ & - & - & - & - \\
14 & 63 & 0,04 & 0,87 & 0,933 & 0,80 & 0,894 \\
15 & 92 & 0,44 & - & - & 0,92 & 0,959 \\
16 & 92 & 0,48 & - & - & - & - \\
17 & 92 & 0,64 & - & - & - & - \\
18 & 92 & 0,36 & - & - & - & - \\
19 & 141 & 0,13 & - & - & 0,70 & 0,837 \\
20 & 141 & $-0,29$ & - & - & - & -
\end{tabular}




\begin{tabular}{|c|c|c|c|c|c|c|}
\hline 21 & 141 & $-0,23$ & - & - & - & - \\
\hline 22 & 141 & 0,12 & - & - & - & - \\
\hline 23 & 141 & $-0,18$ & - & - & - & - \\
\hline 24 & 141 & $-0,10$ & - & - & - & - \\
\hline 25 & 9 & 0,05 & 0,87 & 0,933 & 0,92 & 0,959 \\
\hline 26 & 22 & 0,08 & - & - & - & - \\
\hline 27 & 20 & 0,16 & - & - & - & - \\
\hline 28 & 7 & 0,29 & - & - & - & - \\
\hline 29 & 40 & 0,28 & 0,83 & 0,911 & 0,78 & 0,883 \\
\hline 30 & 40 & 0,28 & - & - & - & - \\
\hline 31 & 40 & 0,2 & - & - & - & - \\
\hline 32 & 40 & 0,16 & - & - & - & - \\
\hline 33 & 60 & 0,19 & 0,85 & 0,922 & 0,84 & 0,917 \\
\hline 34 & 120 & 0,18 & 0,74 & 0,860 & 0,73 & 0,854 \\
\hline & & & 0,78 & 0,883 & 0,65 & 0,806 \\
\hline & & & 0,66 & 0,812 & - & - \\
\hline 35 & 96 & 0,31 & 0,85 & 0,922 & 0,77 & 0,877 \\
\hline & & & 0,82 & 0,906 & - & - \\
\hline & & & 0,75 & 0,866 & - & - \\
\hline & & & 0,87 & 0,933 & - & - \\
\hline & & & 0,85 & 0,922 & - & - \\
\hline & & & 0,74 & 0,860 & - & - \\
\hline & & & 0,95 & 0,975 & - & - \\
\hline & & & 0,93 & 0,964 & - & - \\
\hline 36 & 302 & 0,02 & 0,87 & 0,933 & - & - \\
\hline 37 & 302 & $-0,03$ & 0,92 & 0,959 & - & - \\
\hline 38 & 302 & $-0,01$ & 0,77 & 0,877 & - & - \\
\hline 39 & 302 & 0,06 & - & - & - & - \\
\hline 40 & 302 & $-0,01$ & - & - & - & - \\
\hline 41 & 302 & $-0,06$ & - & - & - & - \\
\hline 42 & 302 & $-0,06$ & - & - & - & - \\
\hline 43 & 302 & $-0,09$ & - & - & - & - \\
\hline 44 & 99 & $-0,179$ & 0,85 & 0,922 & - & - \\
\hline 45 & 99 & $-0,07$ & 0,82 & 0,906 & - & - \\
\hline 46 & 99 & $-0,007$ & 0,75 & 0,866 & - & - \\
\hline 47 & 28 & $-0,354$ & - & - & - & - \\
\hline 48 & 28 & 0,109 & - & - & - & - \\
\hline 49 & 28 & 0,202 & - & - & - & - \\
\hline 50 & 28 & $-0,163$ & - & - & - & - \\
\hline 51 & 28 & $-0,195$ & - & - & - & - \\
\hline 52 & 28 & 0,295 & - & - & - & - \\
\hline 53 & 209 & 0,012 & - & - & - & - \\
\hline
\end{tabular}




\begin{tabular}{|c|c|c|c|c|c|c|}
\hline 54 & 730 & $-0,01$ & 0,70 & 0,837 & 0,67 & 0,819 \\
\hline 55 & 730 & $-0,03$ & 0,61 & 0,781 & - & - \\
\hline 56 & 730 & 0,01 & 0,79 & 0,889 & - & - \\
\hline 57 & 730 & $-0,02$ & 0,63 & 0,794 & - & - \\
\hline 62 & 730 & 0,1 & 0,75 & 0,866 & - & - \\
\hline 59 & 730 & $-0,02$ & 0,62 & 0,787 & - & - \\
\hline 60 & 730 & 0,12 & 0,81 & 0,900 & - & - \\
\hline 61 & 730 & 0,01 & 0,65 & 0,806 & - & - \\
\hline 62 & 730 & 0,1 & 0,75 & 0,866 & - & - \\
\hline 63 & 730 & 0,08 & 0,61 & 0,781 & - & - \\
\hline 64 & 730 & 0,08 & 0,79 & 0,889 & - & - \\
\hline 65 & 730 & 0,09 & 0,61 & 0,781 & - & - \\
\hline 66 & 120 & $-0,04$ & - & - & - & - \\
\hline 67 & 120 & 0,48 & - & - & - & - \\
\hline 68 & 120 & $-0,09$ & - & - & - & - \\
\hline 69 & 419 & 0,01 & - & - & - & - \\
\hline 70 & 253 & 0,08 & 0,81 & 0,900 & 0,526 & 0,725 \\
\hline 71 & 431 & 0,14 & 0,91 & 0,954 & 0,85 & 0,922 \\
\hline 72 & 100 & $-0,015$ & - & - & - & - \\
\hline Jumlah & 15343 & 8,395 & 27,39 & 30,90116 & 10,946 & 12,343 \\
\hline Rerata & 213,09722 & 0,1165972 & 0,782571 & 0,88289 & 0,781857 & 0,881638 \\
\hline SD & 254,68037 & 0,2401275 & 0,09796 & 0,056272 & 0,12136 & 0,070166 \\
\hline
\end{tabular}

Keterangan: $\mathrm{n}=$ jumlah contoh penelitian; $\mathrm{rxx}=$ koefisien reliabilitas alat ukur variabel $\mathrm{X}$; $\mathrm{a}=$ akar kuadrat koefisien reliabilitas alat ukur variabel $\mathrm{X}$; ryy=koefisien reliabilitas alat ukur variabel $\mathrm{Y} ; \mathrm{b}=$ akar kuadrat koefisien reliabilitas alat ukur variabel $\mathrm{Y}$

Berdasarkan Tabel 5, diketahui bahwa terdapat 35 studi dari 72 studi (48,61 persen) yang memiliki informasi tentang alat ukur pengasuhan orangtua dan empat belas studi dari 72 studi (19,44 persen) yang memiliki informasi tentang alat ukur penalaran moral, dan 23 studi dari 72 studi (31,94 persen) yang tidak memiliki informasi tentang alat ukur. Studi yang memiliki nilai koefisien reliabilitas alat ukur pengasuhan orangtua terdiri dari 28 studi dari 45 studi $(62,22$ persen) yang dipaparkan. Ada sepuluh studi dari 72 studi (13,88 persen) yang memiliki nilai koefisien reliabilitas berada di bawah 0,7 . Sepuluh studi tersebut tetap dimasukkan dalam perhitungan agar dapat mengetahui besar kecilnya prosentasi kesalahan pengukuran yang sebenarnya dalam studi meta-analisis ini. 
Keseluruhan nilai reliabilitas alat ukur pada studi ini dilibatkan dalam analisi koreksi kesalahan pengukuran. Berikut adalah langkah-langkah perhitungan koreksi kesalahan pengukuran:

a. Rerata gabungan dihitungan dengan:

$$
\check{A}=A v e(a) A v e(b)=(0,883)(0,882)=0,779
$$

b. Korelasi populasi yang dikoreksi oleh kesalahan pengukuran dihitung dengan:

$$
\rho=\frac{r}{A}=\frac{0,04}{0,779}=0,0513
$$

c. Jumlah koefisien kuadrat variasi dihitung dengan:

$$
V=\frac{S D^{2}(a)}{A v e^{2}(a)}+\frac{S D^{2}(b)}{A v e^{2}(b)}=\frac{(0,056)^{2}}{(0,883)^{2}}+\frac{(0,0702)^{2}}{(0,882)^{2}}=0,0040+0,0063=0,0103
$$

d. Varians yang disebabkan pada artefak kesalahan pengukuran dihitung dengan:

$$
\sigma_{2}^{2}=\rho^{2} A^{2} V=(0,0513)^{2}(0,779)^{2}(0,0103)=0,0000165
$$

e. Variansi korelasi yang sesungguhnya dihitung dengan :

$$
\sigma^{2} \rho=\frac{\sigma^{2} \rho o-\sigma^{2} 2}{A^{2}}=0,0176 \mathrm{SD}=0,133
$$

f. Interval kepercayaan dengan penerimaan $95 \%$ dihitung dengan :

$$
\rho \pm 1,96 S D=-0,20938-0,31198
$$

g. Dampak variansi reliabilitas dihitung dengan:

$$
\frac{\sigma^{2} 2}{\sigma^{2} \mathrm{r}} \times 100 \%=\frac{0,0000165}{0,01568} \times 100 \%=0,1052 \%
$$

Dampak variasi reliabilitas tersebut menunjukkan bahwa korelasi yang berbeda antara rerata populasi dan rerata studi dalam penelitian, yang disebabkan adanya kesalahan pengukuran adalah sebesar $0,1052 \%$.

Koreksi artefak selain kesalahan pengambilan contoh adalah koreksi kesalahan pengukuran. Oleh karena itu, perlu diketahui terlebih dahulu korelasi populasi setelah dikoreksi kesalahan pengukuran $(\rho)$, dalam hal ini telah diketahui sebesar 0,0513. Varian mengacu pada variasi artefak sebesar 0,0000165 sehingga diketahui varian korelasi (SD) yang sesungguhnya sebesar 0,133. Interval kepercayaan yang diperoleh antara $-0,20938<\rho<0,31198$ dan dampak variasi 
reliabilitas sebesar 0,1052 persen. Apabila varian kesalahan pengukuran dibandingkan dengan varian korelasi populasi maka persentase varian yang disebabkan kesalahan pengukuran adalah kecil yaitu sebesar 0,1052 persen. Hasil ini lebih kecil daripada kesalahan pengambilan sampel (29,97 persen). Persentase yang kecil ini menunjukkan kemungkinan bias kesalahan karena kekeliruan dalam pengukuran adalah sangat kecil, walaupun ada tujuh studi yang memiliki nilai koefisien reliabilitas di bawah 0,7 .

Besarnya kesalahan sampel dalam penelitian meta-analisis ini adalah $29,97 \%$. Hal tersebut salah satunya dapat disebabkan oleh heterogenitas sampel yang digunakan oleh penelitian (partisipan mulai dari TK, SD, SMP, SMA, dan bahkan mahasiswa di Perguruan Tinggi). Selain itu, besar kecilnya kesalahan sampel dapat pula ditentukan oleh besar kecilnya sampel. Kesalahan sampel lebih menekankan pada karakteristik dari sampel yang dapat karena variasi sampelnya terlalu banyak atau terlalu sedikit.

\section{Kesimpulan}

Berdasarkan penjelasan di atas, maka dapat disimpulkan bahwa hipotesis yang diajukan dalam studi ini dapat diterima. Artinya pengasuhan memiliki hubungan dengan penalaran moral walaupun hubungannya kecil. Hasil studi ini semakin memantapkan asumsi bahwa pengasuhan orangtua memiliki hubungan dalam meningkatkan ataupun menurunkan penalaran moral. Berdasarkan studi meta-analisis terhadap tiga jenis gaya pengasuhan menunjukkan bahwa ketiga jenis gaya pengasuhan memiliki hubungan dengan penalaran moral walaupun arah hubungannya tidak sama dan besar korelasinya kecil. Hasil kajian meta-analisis ini mendukung penelitian-penelitian sebelumnya tentang pengasuhan dan penalaran moral. Oleh karena itu, pengasuhan merupakan salah satu faktor yang hendaknya dipertimbangkan untuk perkembangan penalaran moral.

Berdasarkan hasil kajian meta-analisis ini maka disarankan bagi peneliti selanjutnya untuk mempertimbangkan karakteristik sampel dengan memberikan batasan sampel yang berkaitan dengan jumlah sampel, usia, dan tingkat pendidikan. Peneliti selanjutnya dapat melakukan studi meta-analisis berdasarkan 
batasan usia tertentu ataupun berdasarkan tingkat pendidikan. Pembatasan karakteristik sampel juga dapat berdasarkan negara asal dari sampel, misalnya melakukan studi meta-analisis khusus pada sampel dari negara-negara dengan karakteristik budaya timur, demikian pula sebaliknya. Faktor budaya perlu dipertimbangkan karena moral sangat berkaitan dengan nilai yang dipegang oleh masing-masing individu yang diturunkan oleh kebiasaan maupun nilai dari budaya setempat, termasuk tentang cara pengasuhan dan penalaran moral setiap individu.

\section{DAFTAR PUSTAKA}

Abad, S. T. R., Taheri, A. M., \& Yakhdani, M. H. F. (2013). Investigating the relationship of parenting styles with creativity and moral development in $\mathrm{m}$, artiale preschoolers in Yazd city. European Journal of Experimental Biology, $3(5), 605-608$.

Azari, S., \& Faramarzi, S. (2014). A study of the relationship between parenting styles and tendency to immoral media in adolescents of asfahan. Journal of Life Science and Biomedicine, 4(2), 103-107.

Boyes, M. C., \& Allen, S. G. (1993). Styles of parent-child interaction and moral reasoning in adolescence. Merrill-Palmer Quarterly, 39(4), 551-570.

Retrieved from http://www.jstor.org/stable/23087249

Carlo, G., Mestre, M. V., Samper, P., Tur, A., \& Armenta, B. E. (2011). The longitudinal relations among dimensions of parenting styles, sympathy, prosocial moral reasoning, and prosocial behaviors. International Journal of Behavioral Development, 35(2), 116-124. https://doi.org/10.1177/0165025410375921

Forney, W. S., Forney, J. C., \& Crutsinger, C. (2005). Developmental stages of age and moral reasoning as predictors of juvenile delinquents 'behavioral intention to steal clothing. Family and Consumer Sciences Research Journal, 34(2), 110-126. https://doi.org/10.1177/1077727X05280666

Giunta, S. A. (2002). Familiar influences on the moral reasoning of adolescent first-time offenders. University of Florida.

Gump, L. S., Baker, R. C., \& Roll, S. (2000). Cultural and gender dDifferences in moral judgment: A study of mexican americans and anglo-americans. Hispanic Journal of Behavioral Sciences, 22(1), 78-93. 
Hart, D. (1988). A longitudinal study of adolescents 'socialization and identification as predictors of adult moral judgment development. MerrillPalmer Quarterly, 34(3), 245-260. Retrieved from http://www.jstor.org/stable/23086383

Hawkins, S. M. (2005). The influence of parenting styles on the development of moral judgment in college level adolescents. Libertyi University.

Hunter, J. E., \& Schmidt, F. L. (2004). Methods of Meta-Analysis. Correcting Error and Bias in Research Finding (Second). California: Sage Publications.

Jankowski, H. (2002). Moral reasoning and its relationship topParenting sStyle, religious commitment, and Gende. Kean University.

Kiitredge, J. S. (1984). Parenting practices and moral judgments of adolescents. University of Virginia.

Kumari, C., \& Khanna, A. (2016). Parenting styles and moral judgment among adolescents. International Journal of Applied Research, 2(2), 572-574.

Retrieved from www.allresearchjournal.com

Malti, T., \& Krettenauer, T. (2013). The relation of moral emotion attributions to prosocial and antisocial behavior : A meta-analysis The Relation of Moral Emotion Attributions to Prosocial and Antisocial Behavior : A MetaAnalysis. Child Development, 84(2), 397-412. https://doi.org/10.1111/j.1467-8624.2012.01851.x

Miners, R. (2001). Parenting style, moral development and fnendship: (How) do we choose our friends. Concordia University.

Pratt, M. W., Arnold, M. L., Pratt, A. T., \& Diessner, R. (1999). Predicting adolescent moral reasoning from family climate: A longitudinal study. The Journal of Early Adolescence, 19(2), 148-175. https://doi.org/10.1177/0272431699019002002

Rashid, A. A., Mamat, A., \& Ibrahim, B. (2014). Barriers to moral development of adolescents and pParental responsibility: The case of malay working parents. International Journal of Humanities Social and Education (IJHSSE), 1(6), 40-48. Retrieved from www.arcjournals.org

Seydoogullari, S. U., Aridag, N. C., \& Koc, M. (2014). The Investigation of moral judgement competence of high school students in terms of parental attitudes. Journal of Faculty of Educational Sciences, 47(2), 21-40.

Speicher, B. (1992). Adolescent moral judgment and perceptions of family iInteraction. Journal of Family Psychology, 6(2), 128-138. 
Vaden, S. R. (2001). The relationship of parenting styles to moral development in college students. The University of Memphis.

Walker, L. J., \& Hennig, K. (1999). Parenting style and the development of moral reasoning. Journal of Moral Education, 28(3), 359-374. https://doi.org/10.1080/030572499103133

Walker, L. J., Hennig, K. H., \& Krettenauer, T. (2000). Parent and peer contexts for children â $€^{\mathrm{TM}} \mathrm{s}$ moral reasoning development. Child Development, 71(4), 1033-1048. Retrieved from http://www.jstor.org/stable/1132342 Accessed:

Walker, L. J., \& Taylor, J. H. (1991). Stage transitions in moral reasoning : A longitudinal study of developmental processes. Developmental Psychology, $27(2), 330-337$.

Yuniarrahmah, E., \& Rachmah, D. N. (2014). Pola asuh dan penalaran moral pada remaja yang sekolah di madrasah dan sekolah umum di Banjarmasin. Jurnal Ecopsy, 1(2), 43-50. 